\title{
The Effects of Perch Cooling on Behavior, Welfare Criteria, Performance, and Litter Quality of Broilers Reared at High Temperatures with Different Litter Thicknesses
}

Original Article

-Author(s)

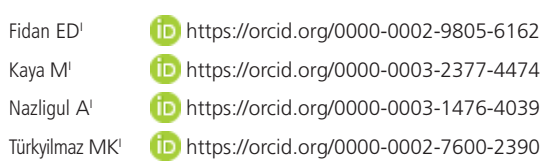

Türkyilmaz MK' (iD https://orcid.org/0000-0002-7600-2390

Faculty of Veterinary Sciences, University of Aydin Adnan Menderes, Department of Animal Sciences, Aydin, Turkey.

\section{-Mail Address}

Corresponding author e-mail address Evrim Dereli Fidan

University of Aydin Adnan Menderes, Faculty of Veterinary Sciences, Department of Animal Sciences, Aydin, Turkey, Code: 09016.

Phone: +90 2562470700

Email: edereli@adu.edu.tr

\section{- Keywords}

Broiler, cool perch, footpad dermatitis, heterophil/lymphocyte ratio, perching.
Submitted: 25/february/2020 Approved: 03/July/2020

\section{ABSTRACT}

The first aim of this study was to investigate the effects of perch cooling and different litter thicknesses on litter quality of the housing facility, welfare criteria (incidence of footpad and hock burns, gait score, plumage cleanliness and damages), heterophil/lymphocyte ratio, growth, and carcass compositions of broilers reared at high ambient temperature. Secondly, the study was conducted to determine whether cooled perches would be preferred by broiler chickens exposed to a hot environment, and subsequently, whether the utilization of these perches would improve the welfare and performance of broilers, beyond those provided by non-cooled perches. A total of 459 1-day-old male broiler chicks were randomly assigned to nine treatment groups based on the perch treatment (no perch, non-cooled, cooled perches) and litter thicknesses $(1,7,14 \mathrm{~cm})$ with three replicates. Aerial ammonia and litter moisture levels were lower in broilers reared at $14 \mathrm{~cm}$ litter thickness group than in broilers reared at $1 \mathrm{~cm}$ thickness group. The perch-contact incidence of chickens reared under the cooled perch was found higher than the non-cooled chickens at 36 to 42 days of age. Cooled perches and $14 \mathrm{~cm}$ of litter thickness tended to decrease the incidence of footpad and hock burn. The body weight gain of the broilers in cooled perch group was higher than those in no perch and non-cooled perch groups at 0-42 $d(p<0.05)$. These results suggest that cool perches have a beneficial effect on the performance and welfare of broilers.

\section{INTRODUCTION}

Excessive requirements of industrial broiler breeding have resulted in undesirable problems such as congenital bone disorders, cardiovascular and respiratory system diseases, leg abnormalities and bone fractures, ascites, and sudden death syndrome (Ventura et al., 2010, 2012; Charuta et al., 2011; Kiyma et al., 2016; Kaukonen et al., 2017). Leg problems of birds may result in important economic damages to broiler breeders, due to poor feed conversion which reduces carcass yield and raise mortality.

Ambient temperatures over $25^{\circ} \mathrm{C}$ can cause heat stress and decrease feed intake to reduce metabolic heat production and maintain homeothermy, resulting in lower body weight (BW), reduced breast muscle yield, higher feed conversion ratio (FCR) (Lara \& Rostagno, 2013; Mello et al., 2015), possibly higher mortality, and poor health and welfare (Khan et al., 2012).

In this context, perch cooling is drawing attention as a new alternative system in hot conditions. Broiler chickens benefit from the cooling effect of water-chilled perches by body contact, allowing heat transfer to the perch (Estevez et al., 2002; Zhao et al., 2012; Hu et al., 
Fidan ED, Kaya M,

Nazligul A, Türkyilmaz MK
The Effects of Perch Cooling on Behavior, Welfare Criteria, Performance, and Litter Quality of Broilers Reared at High Temperatures with Different Litter Thicknesses
2016; Strong et al., 2016). Moreover, perch cooling may generate the required motivation of broilers for perching. Zhao et al. (2012) reported a significant decrease in the incidence of footpad dermatitis (FPD) and hock burn (HB), and abdominal plumage status in broiler chickens subjected to cooled perches. In broiler breeding, there is a direct connection between litter material and body temperatures of birds because of heat transmission. For this reason, litter thickness is another important factor that affects broiler welfare and performance in hot conditions (Shao et al., 2015). Previous studies demonstrated that birds reared on thin litter had a decreased prevalence of FPD compared to those reared on deeper litter (Ekstrand et al., 1997; Meluzzi et al., 2008). However, Shao et al. (2015) reported that birds reared on thicker sawdust litter scored better concerning welfare parameters such as plumage cleanliness, FPD, hock swelling, and breast blister.

Briefly, high ambient temperature is known as one of the most important management problems causing detrimental effects on broiler welfare and production. And, to best of our knowledge, recent researches on litter have primarily focused on litter materials, no work has been reported on both cooled perch and litter thickness. Therefore, the primary objective of this study was to evaluate the effects of perch cooling and using different litter thicknesses on litter quality variables (ammonia $\left(\mathrm{NH}_{3}\right)$, moisture, and $\mathrm{pH}$ ), welfare criteria (FPD, HB, gait score (GS), plumage cleanliness and damage, breast blister and burn), and heterophil/ lymphocyte $(\mathrm{H} / \mathrm{L})$ ratio, behavior, and performance parameters in summer conditions.

\section{MATERIALS AND METHODS}

\section{Birds and husbandry}

This study was carried out at the Poultry Breeding Unit of Aydin Adnan Menderes University. The study was performed with the permission of the Aydin Adnan Menderes University Animal Experimentation Local Ethics Committee (No: 13.06.2017-64583101/049).

In this study, 459 1-d-old male broiler chicks (Ross308) were acquired from the commercial hatchery and allocated into 9 treatment groups. A $3 \times 3$ factorial arrangement of treatments was applied according to a completely randomized design. The treatments consisted of 3 perch applications (no perch (control), non-cooled and cooled perches) and 3 litter thicknesses (1, 7, and $14 \mathrm{~cm}$ litter thicknesses of pine wood shavings). The treatments were replicated 3 times with
17 birds in each. Chicks of each treatment were placed in separate floor pens measuring $110 \times 150 \mathrm{~cm}$, width $x$ length, respectively. All replications and treatments were carried out at the same time and at the same barn. Day old chicks were individually weighed, wing tagged, and grouped based on their average weights. In each replicate, one round feeder and three nipple drinkers were installed for ad libitum feeding and watering. All chicks were fed with balanced diets (1$14 \mathrm{~d} ; 3050 \mathrm{kcal} \mathrm{ME} / \mathrm{kg}, 23.5 \%$ crude protein, $15-28$ d; $3150 \mathrm{kcal} \mathrm{ME} / \mathrm{kg}, 22 \%$ crude protein, and 29-42 d; $3200 \mathrm{kcal} \mathrm{ME} / \mathrm{kg}, 21 \%$ crude protein) (NRC, 1994).

According to the recent EU guidelines (2007), photoperiod lengths were applied as continuous lighting (24 h light) for 1 to $7 \mathrm{~d}$ and 40 to 42 days and 18L:6D for 8 to 39 days. The brooding temperature was set to $34^{\circ} \mathrm{C}$ for the first $3 \mathrm{~d}$ and was reduced gradually to $31^{\circ} \mathrm{C}$ at the end of the first week for all pens. Mechanical ventilation was controlled separately by a chamber with exhaust fans running $15 \mathrm{~min}$ on and 120 min off for the first 2 weeks and 15 min on and 60 min off thereafter. From 2 to 6 wk of age, exhaust fans overrode the timer when the chamber ambient temperature was reached.

The air temperature and relative humidity were recorded continuously in three median points of each pen, at the height of the bird's eye $(10-30 \mathrm{~cm}$, following the growth of animals). Measurements were performed for four times in a day by using dataloggers at 08:00, 12:00; 16:00 and 20:00 hours throughout the experiment. The dataloggers had a resolution of $1 \%$ (humidity) and $0.1^{\circ} \mathrm{C}$ (temperature).

\section{Experimental design}

The perches used in non-cooled and cooled perch treatments were identical and consisted of galvanized steel pipes ( $1.1 \mathrm{~m}$ length, $3.0 \mathrm{~cm}$ in diameter). In terms of perch application, 18 steel perches $(9$ cooled and 9 non-cooled perches) were horizontally attached 10 $\mathrm{cm}$ above the pen litter as to experimental design. For the motivation of birds, the position of both cooled and non-cooled perches was set to make chicks to pass over the perch for feeding and drinking (Figure 1). For the cooling process, 9 out of the 18 perches were connected to the water cooler (Cihso 2000, Cihan Cooling Ltd. Co., Aydin, Turkey), which is capable of cooling and enables circulation of $5 \mathrm{~L} / \mathrm{min}$ water at $10^{\circ} \mathrm{C}$ through the pipes. Water temperature in cooled perches was controlled twice a day. The chickens were exposed to the perches from day 1, and the cooling process was initiated on day 14 . Cooling was provided for the rest of the experiment period. 
Fidan ED, Kaya M,

Nazligul A, Türkyilmaz MK
The Effects of Perch Cooling on Behavior, Welfare Criteria, Performance, and Litter Quality of Broilers Reared at High Temperatures with Different Litter Thicknesses

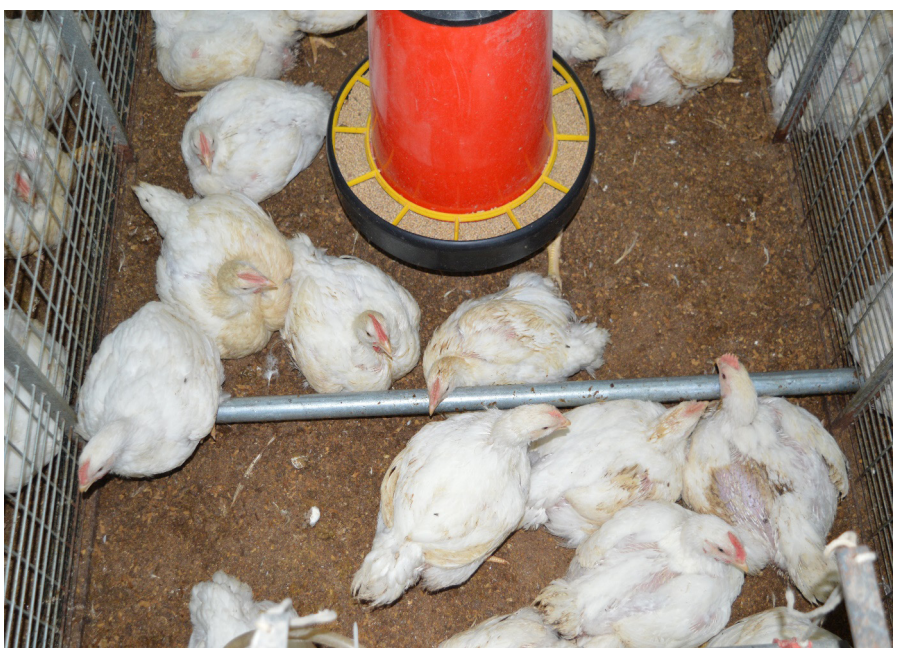

Figure 1 - The perching and perching-contacting behaviors of broiler chickens in cooled perch groups. And, the design of the pens in cooled perch treatment; locations of perch and feeder in a pen.

\section{Traits measured}

\section{Litter quality}

Aerial $\mathrm{NH}_{3}$ concentration, litter moisture content and $\mathrm{pH}$ were measured on the $41^{\text {st }}$ day of age. The $\mathrm{NH}_{3}$ concentration was measured to quantify air quality in each pen by using $\mathrm{NH}_{3}$ gas detector (Dräger $\mathrm{X}$-am ${ }^{\circledR} 5000$, DrägerSafetyAG and Co. KGaA, Revalstrasse 1, 23560, Lübeck, Germany) approximately $0.3 \mathrm{~m}$ above the litter surface. Litter moisture was measured by weighing a $100 \mathrm{~g}$ sample of litter from different places (4 corner and 1 central sample) of each pen, drying sample for $72 \mathrm{~h}$ at $65^{\circ} \mathrm{C}$ in an oven, and then weighing the sample again (Shao et al., 2015). The pH meter (Hanna; HI 9124, Hanna Inst. Inc. Woonsocket RI, US) was inserted into the litter from different sites in each pen to measure the litter $\mathrm{pH}$.

\section{Perching and perch-contacting behaviors}

Broiler chicken behaviors were evaluated by using a video recording program. Daily perching behaviors of birds were monitored and recorded with this program from days 22 to 42 with cameras (ICU, IC B400 IP4MPH265, Beylerbeyi, Turkey) which were placed on the top of each pen. These $24 \mathrm{~h}$ camera recordings were investigated with the instantaneous scanning technique (Estevez et al., 2002) at 04:00, 08:00, 12:00, $16: 00,20: 00$, and 00:00 hours. In other words, a total of $18 \mathrm{~min}$ of recording period ( 3 minutes for each hour) for each day was evaluated. The number of broilers perching, perch-contacting, and other behaviors were counted in each pen. In this assessment, if the bird was standing, sitting, or walking with both feet on the perch and staying at least $2 \mathrm{~s}$, it was defined as perching behavior (Zhao et al., 2013). However, if the chicken wasn't perching, but was in physical contact with the perch (perch-contacting) (e.g., touching bird's body parts such as head, neck, breast, or wing on the perch), these animals were evaluated as animals being in contact with the perch. Behaviors other than perching and perch contacting were considered as other behavior (e.g. eating, drinking, walking, and resting on the floor).

\section{Welfare criteria and heterophil/lymphocyte ratio}

At the end of the study (at d 42), 7 chickens from each pen were randomly picked to evaluate welfare criteria (FPD, HB, hock swelling, GS, plumage cleanliness and damage, breast blister and burn) and $\mathrm{H} / \mathrm{L}$ ratio. FPD scoring comprised of a 5-point scale as follows: score 0 was assigned to footpads with no lesions (good), score 1 and 2 to those with a minimal lesion affecting a very small area of skin (fair), and score 3 and 4 were given when the footpad had a grossly affected region with lesion covering most of the footpad area (poor) (Welfare Quality ${ }^{\circledR}, 2009$ ). The scoring of HB lesions comprised of a 5-point scale. HB mild superficial lesions (score 1 and 2) were judged to be no trouble or disorder and they were combined with category 0 (not affected). The ulcerative lesions (score 3 and 4) were assigned as a painful condition (Welfare Quality $^{\circledR}$, 2009). Gait score was determined by using the 0-to-5 scale (0: excellent gait and 5: deficiency stand) (Welfare Quality ${ }^{\circledR}, 2009$ ). Plumage cleanliness was assessed from the ventral side of the bird with scores; 0 : completely clean feathers, 1 : moderately dirty feathers (soiling feathers localized in the breast and abdominal areas without caked dirt), and 2: very dirty feathers (extensive dirt on abdomen and wings) (Welfare Quality ${ }^{\circledR}$, 2009). Plumage damage of each bird was scored visually from 0 (fully feathered) to 5 (bald) in thigh, wing, tail, and back areas as reported by Kretzschmar-McCluskey et al. (2014). After slaughter, the birds were examined for breast blisters and burns. The breast blister and burn scoring systems were a two-point visual ranking system, where a score of 0 indicated breast with no lesions present and a score of 1 indicated breast with lesions (Welfare Quality ${ }^{\circledR}$, 2009). Blood samples $(1 \mathrm{ml})$ from the wing vein were taken into EDTA containing tubes for heterophil and lymphocyte counting (Gross \& Siegel, 1983).

\section{$B W$ gain, Feed intake, FCR, viability, and carcass composition}

The BW gain and feed intake were measured weekly. FCR of related periods was calculated. Broiler 
viability was recorded for each pen on a daily basis from which the total viability rate was calculated (0-42 d). On the $42^{\text {nd }} d$ of age, 7 randomly selected broilers from each pen were weighed, hung on shackles, and electrically stunned (50 V, 20 mA, $400 \mathrm{~Hz}$ ). Killing was by a single cut severing the right carotid artery and jugular vein. As carcass parts, the deboned total breast meat (fillets and tenders) and legs (thighs and drums) were harvested and weighed individually. The yield parts of the carcass are expressed as percentages of carcass weight.

\section{Statistical analysis}

Statistical analysis were performed using $\mathrm{IBM}^{\circledR}{ }^{\circledR}$ SPSS ${ }^{\circledR}$ (SPSS, Version 22.0; Chicago, IL, USA). Data were tested for distribution normality and homogeneity of variance. Litter moisture and carcass yield part yields data were transformed to arcsine values before analysis, and the significance level was set at $p<0.05$. Litter quality (aerial $\mathrm{NH}_{3}$, moisture content and $\left.\mathrm{pH}\right), \mathrm{H} / \mathrm{L}$ ratio, $\mathrm{BW}$ gain, feed intake, FCR, and carcass composition (total breast and leg, thighs and drum yields) were analyzed using general linear model (GLM) procedure and means were compared using least square difference (LSD). The mathematical model used in the analyses of yield parts investigated traits was: $Y_{i j k k}=\mu+a_{i}+b_{j}+e_{i j k}$ where $Y_{i j k}$ is the response expected independent variables, $\mu$ is the expected mean, as is the effect of perch cooling (no perch, non-cooled and cooled perch), $b_{j}$ is the effect of litter thickness $(1,7$, and $14 \mathrm{~cm}), a_{i j}$ is the effect of perch cooling and litter thickness interaction, eijk is the residual random error. Chi-square test was performed for analyzing differences in behavior (perching, perch- contacting and other behaviors -e.g. eating, drinking, walking, and resting on the floor), welfare criteria (FPD, HB, GS, plumage damage and cleanliness) and viability. Cramer's $\vee$ was used to evaluate effect size for the chi-square test of association.

\section{RESULTS}

Maximum diurnal ambient temperatures in the barn were recorded as $31.4,34.0,34.0$ and $34.2^{\circ} \mathrm{C}$ for $3,4,5$, and 6 wk of age, respectively, which were characteristic for Aydin region in Turkey. The relative humidity ranged from 50 to $60 \%$.

\section{Litter quality}

Aerial $\mathrm{NH}_{3}$ concentration, litter moisture content and $\mathrm{pH}$ are summarized in Table 1. Litter moisture was higher $(p<0.05)$ in broiler chickens subjected to the cooled perch compared to non-cooled perch. Thicker litter thickness had a significantly positive effect on aerial $\mathrm{NH}_{3}$ concentration and moisture content of litter.

\section{Perching and perch-contacting behaviors}

Perching frequency was greater $(7.1 \%)$ in birds subjected to the non-cooled perch compared to cooled perch $(3.9 \%),(p<0.001)$ at 22 to 28 days of age (Table 2). However, the perch-contact frequency was greater in the cooled perch group (42.5\%) than noncooled perch $(13.7 \%)$ on d $28(\chi 2=951.992, d f=2)$, $(p<0.001)$. The frequency of perch-contact $(39.1 \%)$ increased in broiler chickens subjected to $14 \mathrm{~cm}$ litter thickness from 35 to 42 days. At 8 p.m., the highest perching frequency was obtained for broilers in non-

Table 1 - The least square means for aerial ammonia concentration, litter moisture and pH contents in treatment groups at day 42 .

\begin{tabular}{|c|c|c|c|}
\hline Treatment main effects & Aerial ammonia (ppm) & Litter moisture (\%) & Litter pH \\
\hline Expected mean $(\varnothing)$ & 20.8 & 33.3 & 8.5 \\
\hline \multicolumn{4}{|l|}{ Perch treatment } \\
\hline No perch & 20.6 & $33.7^{a, b}$ & 8.4 \\
\hline Non-cooled perch & 21.3 & $29.7^{\mathrm{b}}$ & 8.5 \\
\hline Cooled Perch & 20.6 & $36.5^{a}$ & 8.5 \\
\hline \multicolumn{4}{|l|}{ Litter thickness } \\
\hline $1 \mathrm{~cm}$ & $22.4^{a}$ & $36.3^{a}$ & 8.4 \\
\hline $7 \mathrm{~cm}$ & $20.7^{b}$ & $33.2^{a, b}$ & 8.5 \\
\hline $14 \mathrm{~cm}$ & $19.4^{c}$ & $30.4^{b}$ & 8.4 \\
\hline SEM $^{1}$ & 0.146 & 0.964 & 0.025 \\
\hline Treatment effects & $p$ value & $p$ value & $\mathrm{p}$ value \\
\hline Perch & 0.125 & 0.017 & 0.828 \\
\hline Litter thickness & $<0.001$ & 0.048 & 0.817 \\
\hline Perch $X$ Litter thickness & 0.051 & 0.977 & 0.749 \\
\hline
\end{tabular}

$a, b, c$ Means with different superscript letters in the same column differ $(p<0.05)$,

'Standard Error of the Mean 
Table 2 - Effect of cooled perch and litter thickness on the perching (\%), perch-contacting (\%) and other behaviors (eating, drinking, walking, and resting on the floor) at 22 to 28,29 to 35 , and 36 to 42 days of age.

\begin{tabular}{|c|c|c|c|c|c|c|}
\hline \multirow[b]{2}{*}{ Factors } & \multicolumn{6}{|c|}{ Perching, perch-contacting and other behaviors (\%) from days 22-28 } \\
\hline & Perching & Perch-contacting & $\begin{array}{l}\text { Eating, drinking, walking, and resting on the } \\
\text { floor }\end{array}$ & $x^{2}$ & $\mathrm{p}$ & Cramer's V \\
\hline \multicolumn{7}{|l|}{ Perch treatment } \\
\hline Non-cooled perch & $7.1^{\mathrm{a}}$ & $13.7^{\mathrm{b}}$ & $79.2^{\mathrm{a}}$ & \multirow{2}{*}{951.992} & \multirow[b]{2}{*}{$<0.001$} & \multirow[b]{2}{*}{0.318} \\
\hline Cooled perch & $3.9^{b}$ & $42.5^{\mathrm{a}}$ & $53.6^{\mathrm{b}}$ & & & \\
\hline \multicolumn{7}{|l|}{ Litter thickness } \\
\hline $1 \mathrm{~cm}$ & $8.4^{\mathrm{a}}$ & $25.9^{b}$ & $65.7^{\mathrm{b}}$ & \multirow{3}{*}{195.925} & \multirow{3}{*}{$<0.001$} & \multirow{3}{*}{0.102} \\
\hline $7 \mathrm{~cm}$ & $4.8^{b}$ & $31.7^{\mathrm{a}}$ & $63.5^{\mathrm{b}}$ & & & \\
\hline \multirow[t]{3}{*}{$14 \mathrm{~cm}$} & $0.4^{c}$ & $29.9^{a}$ & $69.7^{\mathrm{a}}$ & & & \\
\hline & \multicolumn{6}{|c|}{ Perching, perch-contacting and other behaviors (\%) from days 29-35 } \\
\hline & Perching & Perch-contacting & Eating, drinking, walking, and resting on the floor & $x^{2}$ & $\mathrm{p}$ & Cramer's V \\
\hline \multicolumn{7}{|l|}{ Perch treatment } \\
\hline Non-cooled perch & $14.9^{a}$ & $21.1^{\mathrm{b}}$ & $64.0^{\mathrm{a}}$ & \multirow{3}{*}{453.772} & \multirow{3}{*}{$<0.001$} & \multirow{3}{*}{0.230} \\
\hline Cooled perch & $5.2^{\mathrm{b}}$ & $40.4^{a}$ & $54.4^{\mathrm{b}}$ & & & \\
\hline \multicolumn{4}{|l|}{ Litter thickness } & & & \\
\hline $1 \mathrm{~cm}$ & $12.4^{\mathrm{a}}$ & $29.5^{b}$ & $58.1^{\mathrm{a}}$ & \multirow{3}{*}{245.105} & \multirow{3}{*}{$<0.001$} & \multirow{3}{*}{0.120} \\
\hline $7 \mathrm{~cm}$ & $6.2^{b}$ & $37.6^{\mathrm{a}}$ & $56.1^{\mathrm{a}}$ & & & \\
\hline \multirow[t]{3}{*}{$14 \mathrm{~cm}$} & $1.0^{c}$ & $40.3^{\mathrm{a}}$ & $58.7^{a}$ & & & \\
\hline & \multicolumn{6}{|c|}{ Perching, perch-contacting and other behaviors (\%) from days 36-42 } \\
\hline & Perching & Perch-contacting & Eating, drinking, walking, and resting on the floor & $x^{2}$ & $\mathrm{p}$ & Cramer's V \\
\hline \multicolumn{7}{|l|}{ Perch treatment } \\
\hline Non-cooled perch & $7.5^{\mathrm{a}}$ & $13.7^{\mathrm{b}}$ & $78.8^{a}$ & \multirow{3}{*}{882.980} & \multirow{3}{*}{$<0.001$} & \multirow[t]{3}{*}{0.259} \\
\hline Cooled perch & $5.3^{b}$ & $39.2^{\mathrm{a}}$ & $55.5^{b}$ & & & \\
\hline \multicolumn{4}{|l|}{ Litter thickness } & & & \\
\hline $1 \mathrm{~cm}$ & $7.9^{a}$ & $25.2^{\mathrm{c}}$ & $66.9^{a}$ & \multirow{3}{*}{294.764} & \multirow{3}{*}{$<0.001$} & \multirow{3}{*}{0.106} \\
\hline $7 \mathrm{~cm}$ & $5.5^{b}$ & $35.4^{\mathrm{b}}$ & $59.1^{\mathrm{b}}$ & & & \\
\hline $14 \mathrm{~cm}$ & $1.5^{c}$ & $39.1^{\mathrm{a}}$ & $59.4^{\mathrm{b}}$ & & & \\
\hline
\end{tabular}

a,b, Means with different superscript letters in the same column differ $(p<0.05)$.

cooled perch and $1 \mathrm{~cm}$ litter thickness groups (11.5 and $11.6 \%$, respectively) (Table 3 ).

\section{Welfare criteria and heterophil/ lymphocyte ratio}

There were significant differences between perch treatments in terms of FPD in broilers $(\chi 2=11.036$, $d f=4)(p<0.05)$, such that scores defined as good $(96.8 \%)$ were more frequent in the cooled perch group. The broiler chickens reared in $14 \mathrm{~cm}$ litter thickness had lower incidence of HB lesions compared to their corresponding opposite groups $(p<0.001)$ (Table 4$)$. Plumage cleanliness was statistically different between perch or litter thickness groups (Table 4). Litter thickness had a statistically effect on thigh, wing, and tail plumage damages (Table 5). In this study, hock swelling, breast blister and burn were not seen in either perch or litter thickness groups. The $\mathrm{H} / \mathrm{L}$ ratio was found as $0.4,0.3$, and 0.2 for no perch, non-cooled and cooled perch groups, respectively $(p<0.001)$ (Table 6).

\section{BW gain, Feed intake, FCR, viability, and carcass composition}

The BW gain was found the highest in cooled perch $(p<0.05)$ and $1 \mathrm{~cm}$ litter thickness groups $(p<0.001)$ at 0-42 d (Table 6). It is understood that perch treatment significantly affected the total breast, total leg, and thighs yields $(p<0.001)$ (Table 6$)$. The daily feed intake of broilers in $14 \mathrm{~cm}$ litter thickness group was lower compared with those in $1 \mathrm{~cm}$ thickness group at 28 to 35 and 35 to 42 days of age (Table 7). There was no statistical difference between cooled perch group and litter thickness group in terms of viability rate (Table 7).

\section{DISCUSSION}

\section{Litter quality}

Litter condition in deep floor systems of broiler houses in the presence of perch cooling was evaluated according to the Welfare Quality® (2009) protocol. It is known that problems with air quality are more common in deep floor systems and influence bird 
health performance, and welfare (Appleby et al., 2004; Estevez, 2007). In this study, the litter moisture content was the highest (36.5\%) in cooled perch groups. Litter moisture content between 20 and 35\% is accepted as optimal for environmental thermal comfort (Jorge et al., 1997). In this context, it is thought that litter moisture contents (29.7 to $36.5 \%$ ) in the current study were in the range of nearly basal limits. Weber Wyneken et al. (2015) reported that increased litter moisture (49\%) may be responsible for the poorer footpad in turkey. It can be said that high litter moisture content in the cooled perch group could be related to increasing wet litter due to water formation on the pipe surface because of condensation. However, there was no augment trend in the FPD incidence related to increased litter moisture in the cooled perch group.

High concentration of $\mathrm{NH}_{3}$ is a potentially dangerous and unpleasant situation for poultry and producers, respectively. The high litter moisture content is generally associated with an increased $\mathrm{NH}_{3}$, resulting in $\mathrm{NH}_{3}$ concentration increased in the house (Jacob \& Pescatore, 2012). The present study showed that the litter moisture and aerial $\mathrm{NH}_{3}$ contents decreased with increasing litter thickness. In another study (Shao et al., 2015) the authors reported that similar findings were found as the litter moisture in the 12 and 16 $\mathrm{cm}$ litter thickness treatments (25.90 and $25.65 \%$, respectively) was lower than in the 4 and $8 \mathrm{~cm}$ litter treatments (42.78 and $38.33 \%$, respectively). In the same study, the effect of litter thickness on aerial $\mathrm{NH}_{3}$ concentration was found to be statistically significant (Shao et al., 2015). In this study, when litter thickness was $1 \mathrm{~cm}$, it had poor quality, high moisture and aerial $\mathrm{NH}_{3}$ contents. For this reason, an increasing trend in FPD and HB incidence, GS, plumage cleanliness, wing and tail plumage damages could be observed over 1 $\mathrm{cm}$ litter thickness. In a study, the $\mathrm{NH}_{3}$ concentrations of up to 15-20 ppm are acceptable (Sainsbury, 1992). In this context, it was thought that aerial $\mathrm{NH}_{3}(19.4$ to $22.4 \mathrm{ppm}$ ) was slightly over the range of basal limits.

\section{Perching and perch-contacting behaviors}

The broilers in non-cooled perch group had higher perching frequency, but lower perch-contacting frequency, compared with the broilers in cooled perch group at 22 to 28,29 to 35 , and 36 to 42 days of age. In agreement with the findings of previous studies using non-cooled perches (Le Van et al., 2000; PettitRiley \& Estevez, 2001; Zhao et al., (2012), the use of non-cooled perches (perching or perch-contact) increased with age and peaked at 29 to 35 days of age, and then decreased. At 4 a.m., the highest perch- 
Table 4 - Effect of cooled perch and litter thickness on the incidence of footpad dermatitis and hock burn, gait score, and plumage cleanliness in broilers at day 42.

\begin{tabular}{|c|c|c|c|c|c|c|c|c|c|c|c|c|c|c|}
\hline & \multicolumn{14}{|c|}{ Incidence of Footpad Dermatitis (\%) } \\
\hline & \multicolumn{3}{|c|}{ Good } & \multirow[t]{2}{*}{$\mathrm{n}$} & \multicolumn{2}{|l|}{ Fair } & $\mathrm{n}$ & \multicolumn{2}{|c|}{ Poor } & \multicolumn{2}{|c|}{$\mathrm{X}^{2}$} & $p$ & \multicolumn{2}{|c|}{ Cramer's V } \\
\hline \multicolumn{14}{|l|}{ Perch treatment } & \\
\hline No perch & 52 & \multicolumn{2}{|l|}{$82.5^{a}$} & 5 & $7.9^{\mathrm{a}}$ & & 6 & \multicolumn{2}{|c|}{$9.5^{a}$} & \multirow{3}{*}{\multicolumn{2}{|c|}{11.036}} & \multirow[b]{2}{*}{0.026} & \multirow{3}{*}{\multicolumn{2}{|c|}{0.171}} \\
\hline Non-cooled perch & 59 & \multirow{2}{*}{\multicolumn{2}{|c|}{$\begin{array}{c}93.7^{a, b} \\
96.8^{a}\end{array}$}} & 3 & $4.8^{\mathrm{a}}$ & & 1 & \multirow{2}{*}{\multicolumn{2}{|c|}{$1.6^{a, b}$}} & & & & & \\
\hline Cooled perch & 61 & & & 2 & $3.2^{\mathrm{a}}$ & & 0 & & & & & & & \\
\hline \multicolumn{15}{|l|}{ Litter thickness } \\
\hline $1 \mathrm{~cm}$ & 55 & \multicolumn{2}{|l|}{$87.3^{a}$} & 7 & $11.1^{\mathrm{a}}$ & & 1 & \multicolumn{2}{|c|}{$1.6^{a}$} & \multirow{3}{*}{\multicolumn{2}{|c|}{9.760}} & & \multirow{3}{*}{\multicolumn{2}{|c|}{0.161}} \\
\hline $7 \mathrm{~cm}$ & 56 & $88.9^{a}$ & & 3 & $4.8^{\mathrm{a}, \mathrm{b}}$ & & 4 & & $B^{a}$ & & & 0.045 & & \\
\hline $14 \mathrm{~cm}$ & 61 & $96.8^{a}$ & & 0 & - & & 2 & & $2^{a}$ & & & & & \\
\hline \multirow[t]{2}{*}{ Factors } & & & & & & & denc & of $\mathrm{Ho}$ & $\mathrm{kBu}$ & $(\%)$ & & & & \\
\hline & $\mathrm{n}$ & Good & & $\mathrm{n}$ & Fair & & $\mathrm{n}$ & & & $X^{2}$ & & $p$ & Cram & a's V \\
\hline Perch treatment & & & & & & & & & & & & & & \\
\hline No perch & 14 & $22.2^{\mathrm{a}}$ & & 40 & $63.5^{\circ}$ & & 9 & & & & & & & \\
\hline Non-cooled perch & 18 & $28.6^{\mathrm{a}}$ & & 43 & $68.3^{\circ}$ & & 2 & & $2^{b}$ & 10.2 & & 0.036 & 0.1 & \\
\hline Cooled perch & 25 & $39.7^{\mathrm{a}}$ & & 30 & $47.6^{\circ}$ & & 8 & & $7^{\mathrm{a}}$ & & & & & \\
\hline Litter thickness & & & & & & & & & & & & & & \\
\hline $1 \mathrm{~cm}$ & 9 & $14.3^{b}$ & & 40 & $63.5^{\circ}$ & & 14 & & & & & & & \\
\hline $7 \mathrm{~cm}$ & 19 & $30.2^{a, b}$ & & 40 & $63.5^{\circ}$ & & 4 & & & 26.02 & & $<0.001$ & 0.2 & \\
\hline $14 \mathrm{~cm}$ & 29 & $46.0^{a}$ & & 33 & $52.4^{a}$ & & 1 & & $5^{\mathrm{b}}$ & & & & & \\
\hline Factors & & & & & & & & it Scor & $(\%)$ & & & & & \\
\hline & $n$ & s: 0 & $n$ & S: 1 & $n$ & s: 2 & $n$ & S: 3 & $n$ & S: 4 & $n$ & $\begin{array}{l}\text { S: } \\
5\end{array}$ & $p$ & Cramer's V \\
\hline Perch treatment & & & & & & & & & & & & & & \\
\hline No perch & 43 & $65.1^{b}$ & 17 & $28.6^{a}$ & 3 & $6.3^{\mathrm{a}}$ & 0 & - & 0 & - & 0 & - & & \\
\hline Non-cooled perch & 45 & $71.4^{a, b}$ & 16 & $25.4^{\mathrm{a}}$ & 2 & $3.2^{\mathrm{a}}$ & 0 & - & 0 & - & 0 & - & 0.037 & 0.164 \\
\hline Cooled perch & 55 & $87.3^{a}$ & 8 & $12.7^{a}$ & 0 & - & 0 & - & 0 & - & 0 & 10.213 & & \\
\hline Litter thickness & & & & & & & & & & & & & & \\
\hline $1 \mathrm{~cm}$ & 51 & 77.8 & 10 & 17.5 & 2 & 4.8 & 0 & - & 0 & - & 0 & - & & \\
\hline $7 \mathrm{~cm}$ & 48 & 76.2 & 15 & 23.8 & 0 & - & 0 & - & 0 & - & 0 & 4.298 & 0.367 & 0.107 \\
\hline $14 \mathrm{~cm}$ & 44 & 69.8 & 16 & 25.4 & 3 & 4.8 & 0 & - & 0 & - & 0 & - & & \\
\hline Factors & & & & & & cidenc & of & umage & Clea & ness $\left({ }^{\circ}\right.$ & & & & \\
\hline & $n$ & Score 0 & $\mathrm{n}$ & & score 1 & & 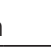 & & re 2 & & $x^{2}$ & $p$ & Crar & her's V \\
\hline Perch treatment & & & & & & & & & & & & & & \\
\hline No perch & 6 & $9.5^{a}$ & 23 & & $36.5^{b}$ & & 4 & & $0^{\mathrm{a}}$ & & & & & \\
\hline Non-cooled perch & 8 & $12.7^{\mathrm{a}}$ & 28 & & $44.4^{a, b}$ & & 7 & & $9^{a, b}$ & & 656 & 0.047 & & 160 \\
\hline Cooled perch & 9 & $14.3^{a}$ & 37 & & $58.7^{a}$ & & 7 & & $0^{\mathrm{b}}$ & & & & & \\
\hline Litter thickness & & & & & & & & & & & & & & \\
\hline $1 \mathrm{~cm}$ & 3 & $4.8^{b}$ & 26 & & $41.3^{a}$ & & 4 & & $.0^{\mathrm{a}}$ & & & & & \\
\hline $7 \mathrm{~cm}$ & 5 & $7.9^{b}$ & 28 & & $44.4^{\mathrm{a}}$ & & 0 & & $6^{\mathrm{a}}$ & & .580 & $<0.001$ & & 233 \\
\hline $14 \mathrm{~cm}$ & 15 & $23.8^{\mathrm{a}}$ & 34 & & $54.0^{a}$ & & 4 & & $2.2^{\mathrm{b}}$ & & & & & \\
\hline
\end{tabular}

a,b Means with different superscript letters in the same column differ ( $p<0.05$ ), S: score, S:0; excellent gait, S:1; slight gait defect, but unidentifiable; S:2; slight gait defect, identifiable abnormality; $S: 3$; identifiable abnormality, impairs function; $S: 4$; severely impairs function, but capable of walking; $S: 5$; deficiency stand, Score 0 ; clean feathers, Score: 1 ; moderately dirty feathers, Score: 2; very dirty feathers.

contacting frequency (39.8\%) was obtained for broilers in $14 \mathrm{~cm}$ thickness group; whereas, the broilers in 1 $\mathrm{cm}$ thickness group had the lowest perch-contacting frequency $(25.0 \%)$. Frequency of perching ranged from $3.9 \%$ to $14.9 \%$ in perch examined groups at 22 to 42 days. Similarly, Zhao et al. (2013) indicated that perching frequency in broilers was found ranging from 7.47 to $12.8 \%$. Some studies demonstrated much lower perching frequencies (from 1.0 to $2.6 \%$ ) (Su et al., 2000; Pettit-Riley \& Estevez, 2001; Estevez et al.,
2002). It is thought that broilers failed to use perches in these studies because the effort required to jump up to the perch may have exceeded their ability or motivation to do so, especially as the increased weights of the birds exceeded what their legs could handle (Le Van et al., 2000).

The results indicated that perch-contact frequency was greater in the cooled perch group than in the non-cooled perch group at 22 to 28,29 to 35, and 36 to 42 days. These findings were in consistency with 
Table 5 - Effect of cooled perch and litter thickness on the incidence of thigh, wing, tail, and back plumage damage in broilers at day 42 .

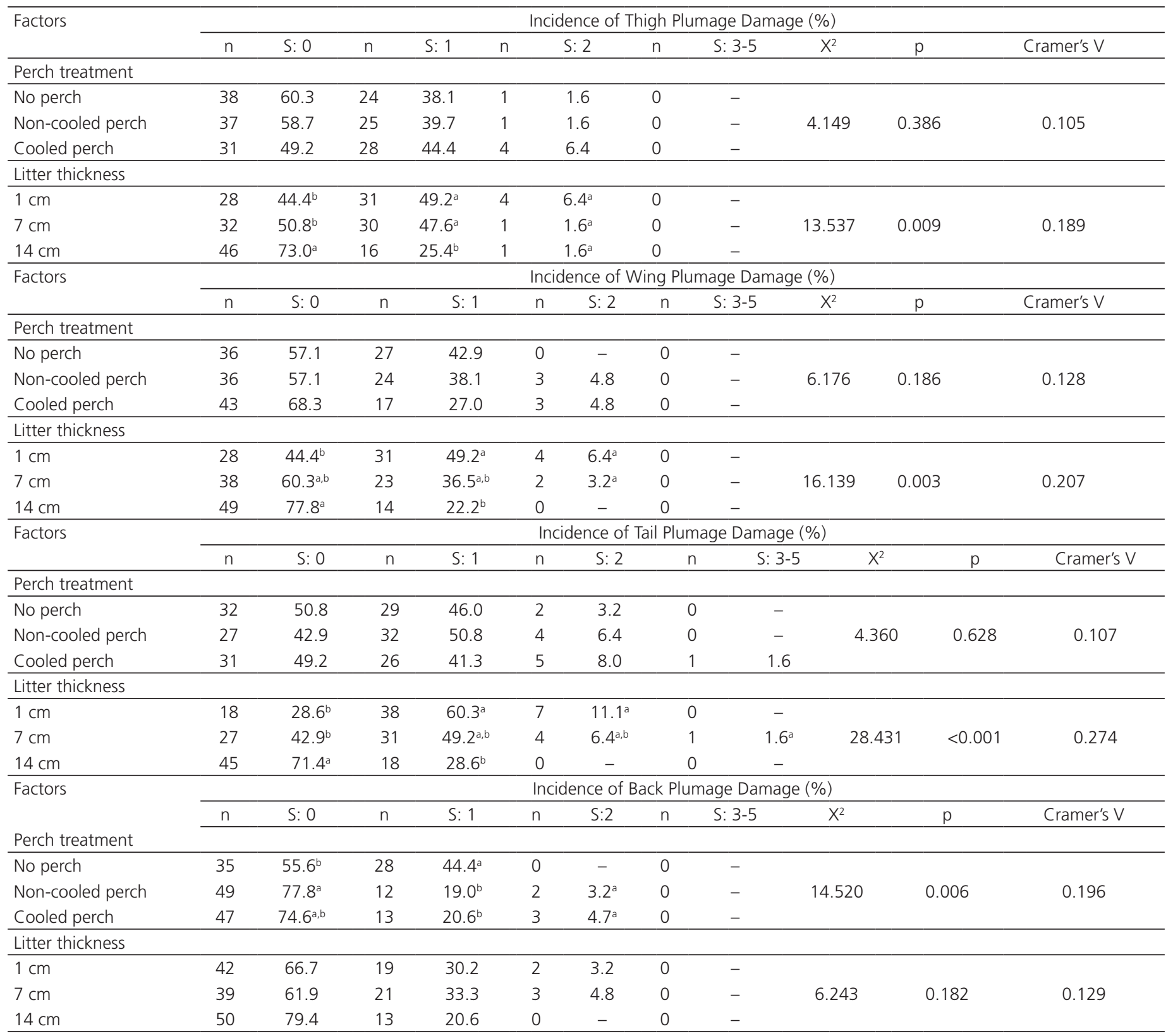

a,b Means with different superscript letters in the same column differ $(p<0.05)$, $S:$ score, $S: 0$; fully feathered, $S: 1 ;$ rough, $S: 2$; some broken feathers, $S: 3$; heavily broken feathers, $S: 4$; almost bald, $\mathrm{S}: 5$; bald.

the other study reporting that if given a choice, birds look for the cooling perch, because it favored heat transfer from the body of broilers to the cooled perch by conduction (Estevez et al., 2002). The higher perchcontacting incidence was obtained in $14 \mathrm{~cm}$ litter thickness group, compared with $1 \mathrm{~cm}$ thickness group from 22 to 28,29 to 35 , and 36 to 42 days of age. This result may be explained by the fact that it is not ideal to increase the thickness of litter, presumably due to depressed thermolysis from the significantly less heat elimination from the body by conduction, because of the reduction in contact with the feet on the ground.
However, the frequency of perching was found greater in $1 \mathrm{~cm}$ litter thickness group than in 7 and $14 \mathrm{~cm}$ thickness group. If there is a prolonged contact with thinnest litters, feet health might be adversely affected and growing sensitivity on the feet could probably lead to FPD and HB. Thus, more frequent perching behavior means more reduced contact of the feet with the floor.

\section{Welfare criteria and heterophil/ lymphocyte ratio}

Research has shown that perch treatments have a stable effect on the development of FPD, HB, GS, 
Table 6 - BW gain, carcass composition, and heterophil/lymphocyte ratio of broiler chickens in response to cooled perch and litter thickness ${ }^{1}$

\begin{tabular}{|c|c|c|c|c|c|c|c|c|c|c|c|}
\hline \multirow[b]{2}{*}{ Treatment main effects } & \multicolumn{6}{|c|}{ Body weight gain (g) } & \multicolumn{4}{|c|}{ Carcass composition (\%) } & \multirow[t]{2}{*}{$\mathrm{H} / \mathrm{L}$} \\
\hline & d 0-7 & d 0-14 & $\mathrm{d} 0-21$ & d 0-28 & d 0-35 & d 0-42 & Total breast & Total leg & Thighs & Drums & \\
\hline Expected mean $(\varnothing)$ & 100.7 & 339.0 & 769.0 & 1321.9 & 1977.4 & 2482.4 & 30.6 & 29.3 & 15.2 & 14.1 & 0.3 \\
\hline \multicolumn{12}{|l|}{ Perch treatment } \\
\hline No perch & 98.6 & 342.8 & 767.9 & $1305.7^{b}$ & $1919.8^{b}$ & $2452.3^{b}$ & $30.2^{b}$ & $29.7^{a}$ & $15.5^{a}$ & 14.2 & $0.4^{\mathrm{a}}$ \\
\hline Non-cooled perch & 100.2 & 347.3 & 770.2 & $1317.6^{\mathrm{a}, \mathrm{b}}$ & $1975.6^{b}$ & $2440.9^{b}$ & $30.3^{b}$ & $29.5^{a}$ & $15.4^{\mathrm{a}}$ & 14.2 & $0.3^{\mathrm{a}}$ \\
\hline Cooled Perch & 103.3 & 326.8 & 767.7 & $1342.4^{\mathrm{a}}$ & $2036.7^{\mathrm{a}}$ & $2554.0^{\mathrm{a}}$ & $31.7^{\mathrm{a}}$ & $28.6^{\mathrm{b}}$ & $14.7^{\mathrm{b}}$ & 13.9 & $0.2^{\mathrm{b}}$ \\
\hline \multicolumn{12}{|l|}{ Litter thickness } \\
\hline $1 \mathrm{~cm}$ & 103.6 & 344.73 & 780.0 & $1343.5^{\mathrm{a}}$ & $2059.7^{a}$ & $2617.7^{\mathrm{a}}$ & 31.00 & 29.03 & 14.96 & 14.08 & 0.3 \\
\hline $7 \mathrm{~cm}$ & 97.4 & 331.58 & 764.9 & $1305.5^{b}$ & $1936.4^{b}$ & $2430.8^{\mathrm{b}}$ & 30.28 & 29.65 & 15.40 & 14.25 & 0.3 \\
\hline $14 \mathrm{~cm}$ & 101.1 & 340.57 & 760.8 & $1316.7^{\mathrm{a}, \mathrm{b}}$ & $1936.0^{b}$ & $2398.8^{\mathrm{b}}$ & 30.64 & 29.09 & 15.14 & 13.96 & 0.2 \\
\hline $\mathrm{SEM}^{2}$ & 1.14 & 3.46 & 3.54 & 5.22 & 11.0 & 17.1 & 0.154 & 0.122 & 0.104 & 0.057 & 0.016 \\
\hline Treatment interaction effects & \multicolumn{6}{|c|}{$p$ value } & \multicolumn{4}{|c|}{$p$ value } & $p$ value \\
\hline Perch & 0.255 & 0.063 & 0.949 & 0.030 & 0.002 & 0.027 & 0.004 & 0.001 & 0.003 & 0.114 & $<0.001$ \\
\hline Litter thickness & 0.111 & 0.308 & 0.091 & 0.023 & $<0.001$ & $<0.001$ & 0.167 & 0.077 & 0.219 & 0.108 & 0.229 \\
\hline Perch $\mathrm{x}$ litter thickness & 0.742 & 0.895 & 0.895 & 0.852 & 0.051 & 0.551 & 0.199 & 0.510 & 0.490 & 0.209 & 0.195 \\
\hline
\end{tabular}

${ }^{1}$ Data presented as the least square means, a,b,c, Means with different superscript letters in the same column differ $(p<0.05)$, ${ }^{2}$ Standard Error of the Mean, H/L: heterophil/lymphocyte ratio.

and plumage cleanliness. Zhao et al. (2012; 2013) reported less severe FPD and HB in broilers reared with cooled perch. Likewise, they reported that the perch cooling resulted in decreased severity of FPD, HB, gait disorders, and back plumage damage. On the other hand, it is seen that non-cooled perches have increased the mentioned lesions. Thus, the use of cooling perch both decreased foot and leg disorders and improved bird's welfare.

In the current study, thicker litter decreased the incidence of FPD and HB in broiler chickens. Also, thicker litter causes cleaner feathers and less plumage damage for thigh, wing and tail parts in broilers. The results are in line with those reported previously by different researchers (Haslam et al., 2007; Shao et al., 2015). In general, FPD can develop quickly, in less than a week, usually associated with wet litter conditions (Shepherd \& Fairchild, 2010; Shao et al., 2015). Dozier et al. (2006) found that increased litter moisture content may be responsible for poor FPD, $H B$, and feathering conditions. Our findings suggested that an increase in litter moisture content resulted in poor leg health and plumage cleanliness and damages. Similar results were recorded on foot and leg health in a thicker litter (Shao et al., 2015). It was thought that there was a developing trend in the foot and leg lesions related to decreasing litter thickness, related to increased litter moisture and continuous standing on wet litter.

The $\mathrm{H} / \mathrm{L}$ ratio is a sensitive indicator of stress, and $0.2,0.5$ and 0.8 characterize low, optimum and high levels of stress, respectively (Siegel \& Gross, 2000). In this study, the highest $\mathrm{H} / \mathrm{L}$ ratio (0.4) was obtained for broilers in no perch group, whereas the broilers in cooled perch group had the lowest $\mathrm{H} / \mathrm{L}$ ratio $(0.2)$. This result suggests that broilers in cooled perch suffered a low level of stress. Zhao et al. (2013) reported that cooled perches had significant effect on plasma glucose concentration as sensitive indicators of stress responses in broiler chickens on the $4^{\text {th }}$ wk. However, Zhao et al. (2013) indicated that cooled perches did not statistically affect blood glucose concentrations on the at $5^{\text {th }}$ and $6^{\text {th }}$ wk. It is thought that there was a decrease in stress levels related to the beneficial effects of the use of cooling perch in broilers. It is believed that further studies should be designed to understand the stress response of broilers exposed to cooled perches.

\section{BW gain, feed intake, FCR, viability, and carcass composition}

In line with a previous study (Zhao et al., 2012; 2013), cooled perches had a statistically significant effect on BW gain on d $0-42$ and FCR on d 35-42. It is said that perch cooling helped the birds in coping with heat stimulation. It is determined that BW gain on $d$ 0-42, and FI on d 35-42 were higher for the broilers reared at $1 \mathrm{~cm}$ litter thickness than those reared at 7 and $14 \mathrm{~cm}$ litter, although the difference between litter groups in terms of FCR on d 35-42 was not statistically significant. The results were found similar to those reported by Demirulus (2006) $(5,8$, and $11 \mathrm{~cm}$ litter thickness), and Shao et al. (2015) (4, 8, 12, and $16 \mathrm{~cm}$ litter thickness). In terms of the BW of the broilers, it can be said that thinner litter would increase FPD and $\mathrm{HB}$ and that decreased activity, physical exercise and perching frequency would improve BW gain. There was 


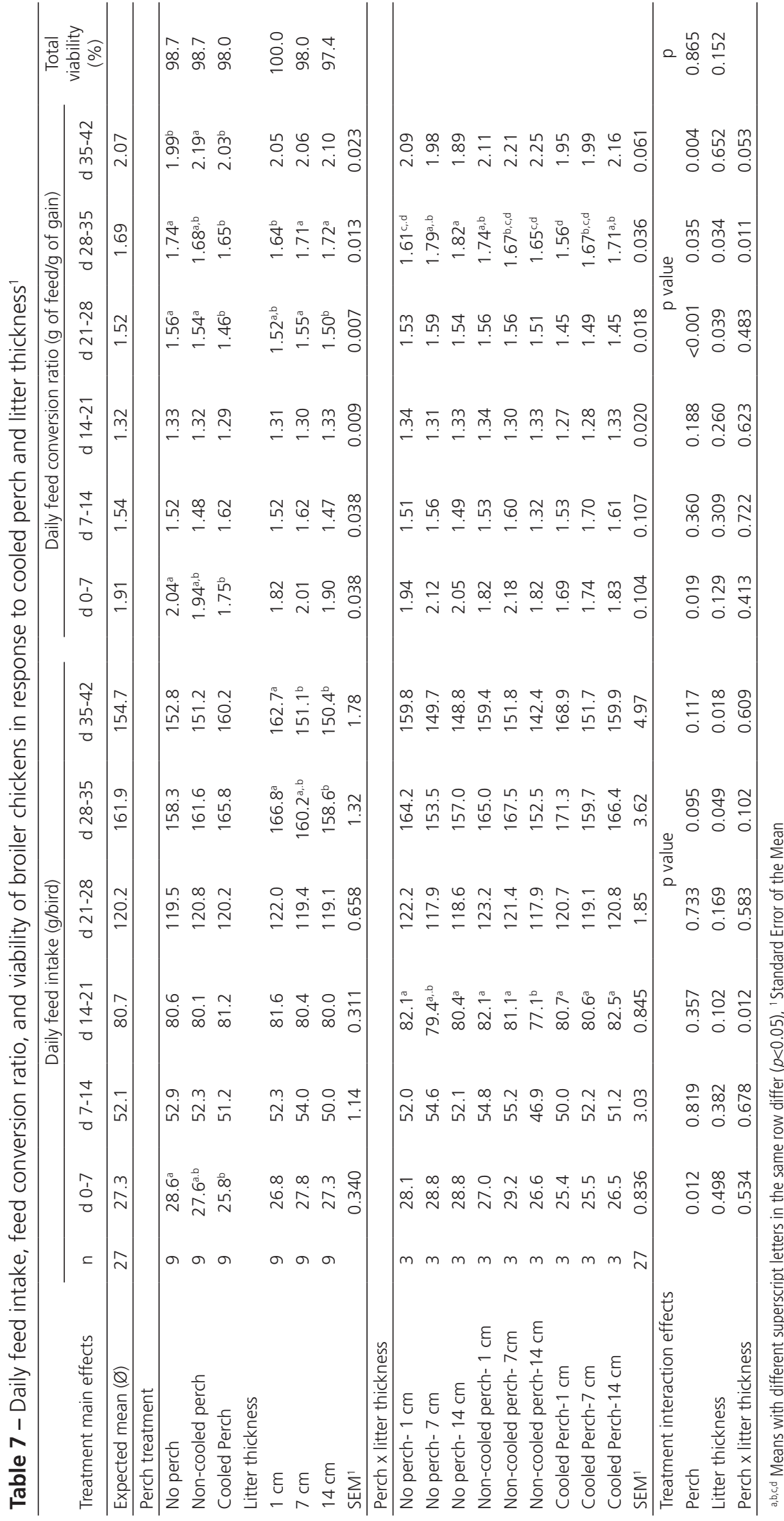

a significant interaction between perch treatment and litter thickness for FCR on d 28-35. It is found that the broilers in cooled perch and 1 $\mathrm{cm}$ litter thickness group had the best FCR (1.56).

Total breast yield was found higher in the cooled perch group than non-cooled and no perch groups. As a parallel to this finding, significant results of increased BW stimulated by cooled perch reflected some beneficial effects in breast yield that is consistent with other studies (Estevez et al., 2002; Zhao et al., 2012). It is thought that perch cooling did promote bird activity and bird mobility, leading to lower total legs and thigh meat yields. On the other hand, cooled perch would be very helpful for decreasing the body temperature by means of both perching and contact with wings or body, resulting in greater breast meat yield. It is suggested that litter thickness has no significant effect on carcass yield parts. Likewise, Zhao et al. (2009) reported that it is more difficult to modify carcass compositions than to change growth performance.

\section{CONCLUSION}

Results indicated that broilers have a higher tendency for using non-cooled perches than cooled perches at high ambient temperatures. It is revealed that birds preferred cooled perches than non-cooled ones for direct contact. It is also understood that cooled perches were very helpful for foot and leg health, stress condition, plumage cleanliness, back plumage damage, growth performance, and total breast meat yield. Thicker litter increased perchcontact behavior of broilers reared at high ambient temperature. The welfare index scores of $F P D, H B$, 
Fidan ED, Kaya M,

Nazligul A, Türkyilmaz MK
The Effects of Perch Cooling on Behavior, Welfare Criteria, Performance, and Litter Quality of Broilers Reared at High Temperatures with Different Litter Thicknesses plumage cleanliness, thigh, wing, and tail plumage damages improved with increasing litter thickness. The aerial $\mathrm{NH}_{3}$ concentration and litter moisture level were significantly related to litter thickness, and they declined with increasing litter thickness. The results showed that $14 \mathrm{~cm}$ litter thickness has a favorable effect on the well-being status of broilers reared at high temperatures. Potential favorable effects on bird welfare and litter quality of perch cooling in broilers raised in thicker litter need to be further investigated.

\section{ACKNOWLEDGEMENTS}

The authors would like to thank the Aydin Adnan Menderes University Research Foundation (ADU-BAP) for the financial support of this work (grant number VTF-17053).

\section{REFERENCES}

Appleby MC, Mench JA, Hughes B.O. Poultry behavior and welfare. Cambridge: CABI Publishing; 2004.

Charuta A, Dzierzecka M, Majchrzak T, Czerwinski E, Cooper G. Computergenerated radiological imagery of the structure of the spongious substance in the postnatal development of the tibio-tarsal bones of the Peking domestic duck (Anas platyrhynchos var. domestica). Poultry Science 2011;90:830-835.

Demirulus $\mathrm{H}$. The effect of litter type and litter thickness on broiler carcass traits. International Journal of Poultry Science 2006;7:670-672.

Dozier WA, Thaxton JP, Purswell JL, Olanrewaju HA, Branton SL, Roush WB. Stocking density effects on male broilers grown to 1.8 kilograms of body weight. Poultry Science 2006;85:344-351.

Ekstrand C, Algers B, Svedberg J. Rearing conditions and foot-pad dermatitis in Swedish broiler chickens. Preventive Veterinary Medicine 1997;31:167-174.

Estevez I. Density allowances for broilers: Where to set the limits? Poultry Science 2007;86:1265-1272.

Estevez I, Tablante N, Pettit-Riley RL, Carr L. Use of cool perches by broiler chickens. Poultry Science 2002;81:62-69.

EU - European Union. Laying down minimum rules for the protection of chickens kept for meat production [EUCD 2007/43/EC]. Official Journal of European Union L 2007;182:19-28.

Gross WB, Siegel HS. Evaluation of the heterophil/lymphocyte ratio as a measure of stress in chickens. Avian Disease 1983;27:972-979.

Haslam SM, Knowles TG, Brown SN, Wilkins LJ, Kestin SC, Warriss PD, et al. Factors affecting the prevalence of foot pad dermatitis, hock burn and breast burn in broiler chicken. British Poultry Science 2007;48:264-275.

Hu JY, Hester PY, Makagon MM, Vezzoli G, Gates RS, Xiong YJ, et al. Cooled perch effects on performance and well-being traits in caged White Leghorn hens. Poultry Science, 2016;95:2737-2746.

Jacob JP, Pescatore AJ. Barley $\beta$-glucan in poultry diets. Annals of Translational Medicine 2014;2:20.
Jorge MA, Martins NRS, Resende, JS. Cama de frango e sanidade avícolaaspectos microbiológicos e toxicológicos. Anais da Conferência APINCO de Ciência e Tecnologia Avícolas; 1997. Campinas: FACTA, 1997. p.24-37.

Kaukonen E, Norring M, Valros A. Perches and elevated platforms in commercial broiler farms: use and effect on walking ability, incidence of tibial dyschondroplasia and bone mineral content. Animal 2017:11:864-871.

Khan RU, Naz S, Nikousefat Z, Selvaggi M, Laudadio V, Tufarelli V. Effect of ascorbic acid in heat stressed poultry. World's Poultry Science Journal 2012;68:477-489.

Kiyma Z, Küçükyılmaz K, Orojpour A. Effects of perch availability on performance, carcass characteristics, and footpad lesions in broilers. Archives Animal Breeding 2016;59:19-25.

Kretzschmar-McCluskey $\vee$, Fisher C, Tuijl OV. A practical guide to managing feather cover in broiler breeder female [ross technotes]. Huntsville: Aviagen Group; 2014

Lara $\mathrm{L}$, Rostagno $\mathrm{MH}$. Impact of heat stress on poultry production. Animal 2013;3:356-369.

Le Van NF, Estevez I, Stricklin WR. Use of horizontal and angled perches by broiler chickens. Applied Animal Behavior Science 2000;65:349-365.

Mello JLM, Boiago MM, Giampietro-Ganeco A, Berton MP, Vieira LDC, Souza RA, et al. Periods of heat stress during the growing affects negatively the performance and carcass yield of broilers. Archivos de Zootecnia 2015;64:339-345.

Meluzzi A, Fabbri C, Folegatti E, Sirri F. Effect of less intensive rearing conditions on litter characteristics, growth performance, carcass injuries and meat quality of broilers. British Poultry Science 2008;5:509-515.

NRC - National Research Council. Nutrient requirements of poultry. $9^{\text {th }}$ ed Washington? National Academy Press; 1994.

Pettit-Riley R, Estevez I. Effects of density on perching behavior of broiler chickens. Applied Animal Behaviour Science 2001;71:127-140.

Sainsbury B. Poultry health and management:chickens, turkeys, ducks, geese and quail. $3^{\text {th }}$ ed. Oxford: Blackwell Scientific Publications; 1992.

Shao D, He J, Lu J, Wang Q, Chang L, Shi SR, et al. Effects of sawdust thickness on the growth performance, environmental condition, and welfare quality of yellow broilers. Poultry Science 2015;94:1-6.

Shepherd EM, Fairchild BD. Footpad dermatitis in poultry. Poultry Science 2010;89:2043-2051.

Siegel PB, Gross WB. General principles of stress and well-being. In: Grandin T, editor. Livestock handling and transport. Wallingford: CABI; 2000. p.27-41.

Strong RA, Hester PY, Eicher SD, Hu J, Cheng HW. The effect of cooled perches on immunological parameters of caged white leghorn hens during the hot summer months. PLoS One 2016;11(3):e0152633.

Su G, Sørensen P, Kestin SC. A note on the effects of perches and litter substrate on leg weakness in broiler chickens. Poultry Science 2000;79:1259-1263.

Ventura BA, Siewerdt F, Estevez I. Effects of barrier perches and density on broiler leg health, fear, and performance. Poultry Science 2010;89:1574-1583.

Ventura BA, Siewerdt F, Estevez I. Access to barrier perches improves behavior repertoire in broilers, PLoS One 2012;7:e29826. 
Fidan ED, Kaya M,

Nazligul A, Türkyilmaz MK
The Effects of Perch Cooling on Behavior, Welfare Criteria, Performance, and Litter Quality of Broilers Reared at High Temperatures with Different Litter Thicknesses

Zhao JP, Jiao HC, Jiang YB, Song ZG, Wang XJ, Lin H. Cool perches improve the growth performance and welfare status of broiler chickens reared at different stocking densities and high temperatures. Poultry Science 2013;92:1962-1971.

Zhao JP, Chen JL, Zhao GP, Zheng MQ, Jiang RR, Wen J. Live performance, carcass composition, and blood metabolite responses to dietary nutrient density in two distinct broiler breeds of male chickens, Poultry Science 2009;88:2575-2584. 